\title{
Current Research Trends in Games for Public Participation in Planning
}

\author{
Viktorija Prilenska, Tallinn University of Technology, Tallinn, Estonia
}

\begin{abstract}
The research, outlined in the paper, explores games as methods for better public participation in planning. Drawing on the thematic analysis of scientific publications, prominent authors and research centres, as well as key research themes, are identified. The themes include motivational aspects of gamified participation, online and pervasive games for massive civic engagement, deliberative and educational games for collective problem-solving, game co-design for questioning and reframing planning concepts. The paper concludes with the benefits of gamification for participatory planning practice.
\end{abstract}

Keywords - Games, literature review, methods, public participation, urban planning.

\section{INTRODUCTION}

The ideas of public participation in planning decisions emerged in the 1960s and since then have been gradually institutionalized [1], [2]. Today, participatory planning is practiced in many parts of the world with varying success [3]. South American and African countries feature some prominent participatory planning examples [1], [4], [5], while some Western countries, which pioneered and developed participatory ideas, are struggling with the decreasing public interest towards participation [6]-[8]. The latter is, arguably, due to the rigidity and complexity of Western planning systems and the inefficiency of traditional civic engagement methods, such as public display [3], [9]-[11]. The efforts to get and keep residents involved, gave rise to a constellation of alternative participation methods, from participatory budgeting to ICT aided participation, among which games occupy a certain niche [12]-[15].

Scopus search results by the items "games", "participation" and "planning" indicate a substantial growth in the number of publications exploring the potential of participatory games since 2011 until today (2019). Some contributions build on applications of well-known commercial games (e.g. SimCity, Minecraft and Pokémon Go), whereas others reflect upon the experiments with non-commercial games specifically developed for participatory purposes (e.g. Community PlanIt, Play [Location], Community Circles) [5], [16]-[20]. Games designed for the purposes beyond entertainment are referred to as "serious games" [21]. In the current article serious games, developed for participatory purposes, are referred to as "participatory games".

Serious gaming entered the planning domain in the 1960s. Early games focused on simulating the relationship between urban policies and regulations, land-uses, population dynamics, infrastructures and ecology [15], [22], [23]. In the course of development, serious planning games diversified their repertoire, focusing, among other topics, on participatory design and plan- ning [24], [25]. In contrast to "play" (from "paidia"), which is an unstructured activity without rules and goals, "game" (from "ludus") is structured by rules to achieve a certain goal [26]. Due to their structured nature and transparency ensuing from the rules and goals, if treated seriously, games may potentially become standalone participation methods at certain planning phases [1].

Research summarized in the current paper draws on recent scientific contributions, and explores the potentials of participatory games for better public participation in planning. The paper indicates a few research centres and authors who have developed a variety of participatory games and published most on the topic. These centres include, but are not limited to, Engagement Lab at Emerson College (USA) and Newcastle University (UK), which focus on games with digital components, Play the City and Play!(UC) (Netherlands), which focus on collaboration fostering board games. The authors include Thiel [20], [27], [28] who focuses on motivational aspects of gamification, Gordon [18], [29], and Devisch [26], [30], [31] who study how games contribute to collective learning, and Poplin [32]-[35] who publishes on various aspects of games.

Furthermore, the paper reveals the topical research themes in the domain of participatory games, namely, the motivational aspects of gamified participation, massive civic engagement by means of online and/or pervasive games, deliberative and educational games for collective problem-solving, game co-design for questioning and reframing planning concepts. The paper concludes with potential application areas for games in participatory planning practice.

\section{Methodology}

Literature review is a summary of published research on the topic conducted by accredited scholars [36], [37]. The generic purpose of the literature review is to provide the context and theoretical foundations for further research, as well as to identify knowledge gaps and establish a benchmark for evaluating the findings [38], [39]. The objective of the current literature review is to acknowledge the advancements in the field of participatory games and to discuss the potential application of participatory games in the planning process.

The literature review focuses on publications about non-commercial games, which were developed for participatory purposes. Publications were sourced from the Scopus database in June 2019 using five sets of search items: (1) "game", "games", "gamified"; (2) "community", "public", "civic"; (3) "participation", "involvement", "engagement"; (4) "urban", "city", "neighbourhood", (5) "planning", "design". The items within each set were separated by a Boolean operator "OR", and the sets were connected by a 
Boolean operator "AND". The years of publications were limited to the last 10 years, from 2009 to 2019 , and the sources of publications - to journals and conference proceedings. The scope of contributions was refined by screening titles, abstracts and keywords, and limited to case studies. Complementary scientific contributions, which provide insights into the topic, were sourced by means of forward and backward reference search.

Table I (see Appendix) contains the list of 22 examined non-commercial participatory games, their brief descriptions, authors and years application, as well as the relevant literature. Out of 22 listed games 20 games were sourced from the literature and 2 games - Energy Game and Participation game, which fit the scope of the research, are developed by the author. The well-known commercial games, such as Geocaching, Minecraft, SimCity, Cities Skylines, Ingress and Pokémon Go, which were either adapted for participatory purposes or generated participatory spin-offs, are not within the scope of the research [5], [17], [30], [40]-[42].

Following the grounded theory approached [39], [43], the body of literature on participatory games was analysed thematically, and seven topical research themes were identified. The vectors were labelled as (1) gamified versus non-gamified methods, (2) information sourcing games, (3) data generation games, (4) pervasive games, (5) deliberative games, and (6) co-designed games. The themes are elaborated and discussed in Section 3, Findings $\&$ Discussion.

Six (out of seven) themes, which relate to specific game characteristics, are positioned according to the framework of participatory methods proposed by [3]. In her seminal article on methodology of participatory planning [3] the author argues that the choice of methods depends upon (1) the context, (2) number and profile of participants, (3) anticipated participation level [44], [45], and (4) participation phase [46], [47].

In the current article, the multifaceted definitions of criteria determining methodological choice and proposed by [3] are simplified. The context, which in [3] is defined as cultural, territorial, institutional, thematic, etc. is narrowed down to the spatial scale. The levels of participation are defined by the type of information flow, where public communication is a one-way information flow from the planning authority to residents, public consultation is a one-way information flow from residents to the planning authority, and public participation is an information exchange between both parties [14], [45]. The planning process is characterized by four phases: initiation, planning, implementation, and maintenance [3], [46], [47].

\section{Findings And Discussion}

\section{A. Gamified Versus Non-gamified Methods}

With the gamification of society, blending game design elements into non-game contexts to attract and retain users has become a ubiquitous practice [73]. "Fun" is a significant motivator for residents to involve in participatory activities [74]. Therefore, a branch of participatory games research is dedicated to studying the differences between gamified and non-gamified participation [28], [59]. The impact of gamification on participation was evaluated in the case studies of smartphone applications for sharing geo-referenced content Community Circles, HINT! and Geo-Zombie for which gamified and non-gamified versions were developed [28], [59]. The aforementioned applications employed reward systems, such as points and leaderboards (Community Circles, HINT!), as well as a narrative appealing to perspective users (Geo-Zombie). The research findings suggest that participants derive "fun" from various aspects. Some players enjoy "gameful" aspects, such as the competitive and captivating gameplay, whereas others are motivated by "serious" aspects, such as the interest in urban environment, opportunities to raise concerns and share ideas, as well as learning and socializing [20], [28], [59], [75], [76]. Although "serious" aspects are the major motivators for engagement in participatory projects, while gamification is a minor motivator, gamification succeeded in increasing participation rates and, specifically, the activity of participants [28], [59]. Game scholars argue, that gamification is often associated and limited to reward systems, which are merely secondary elements structuring the gameplay and measuring progress, while the primary elements are those evoking emotional experiences, providing space for experimentation and generating the state of flow [77]-[80]. Therefore, further research on participatory games should focus on motivational aspects of the latter [28], [81].

\section{B. Information Sourcing Games}

The expansion of Internet connectivity and the growth of digital literacy among all social groups prompted the emergence of online participatory methods. The latter was preceded by established approaches, namely, PPGIS (Public Participation Geographic Information Systems) and citizen science, which used to crowdsource information for planning and scientific purposes by means of paper-based questionnaires [82], [83]. Contemporary online participatory methods employ online platforms or applications for mobile devices, may or may not contain game elements, and collect contributions in the format of geo-referenced texts or images [20], [76], [84], [85]. These methods are usually applied in the early stages of planning, namely, in the initiation and research \& design phases, with the purpose either to source experiential information about the spatial qualities and the patterns of use (e.g. Community PlanIt in Boston and Detroit; Maptionnaire in Helsinki), or to inquire about the opinions on the completed projects (e.g. Stickyworld for the Main Street project in Tallinn; web pages for competition projects in Sippo and Vasaa) [18], [85]-[87]. Compared to face-to-face methods online methods provide the opportunity to participate at any time within a project time frame and from any location, are free from limitation posed by the capacity of meeting spaces, and collect contribution in a structured or semi-structured format [18], [85], [86], [88]. Due to the aforementioned benefits online methods, arguably, are capable of massive outreach and engage the usually underrepresented groups, such as youth and working age citizens [18], [85]. For example, Community PlanIt involved 1,494 participants, of whom in Boston one third were students, and in Detroit two thirds were 
of 35 years old or younger [18], and Community Circles involved 780 participants in Turku [20].

\section{Data Generation Games}

Public participation is often criticized for being non-representative, as it involves a small number of participants of certain profile and, thus, does not reflect the variety of interests within the population [7], [20], [74], [85]. The reasons for non-participation vary from being disinterested about urban issues or unaware about participation opportunities, to taking a rational decision not to participate because the costs of participation outweigh its benefits [8], [89]. The big data opens an opportunity to enquire about the preferences of population groups, including non-participants, indirectly and at a relatively low cost [40], [90]. Data producing technologies, such as environmental, transportation, building management sensor systems, as well as user-generated content, like social media, administrative and census data, etc., generate massive unstructured information [91]. The patterns in the massive unstructured information, discovered by means of data mining methods, enable formulating assumptions about spatial preferences of the residents, which can be partially validated through surveys involving those willing to participate [17], [40], [90], [92]. Games, and specifically participatory games, generate (or are designed to generate) the data revealing the preferences of the players [40], [68], [90]. Although commercial games are excluded from the review, it is worth mentioning that the data generated by commercial location-based games Geocaching, Ingress and Pokémon Go, indicates the points of interest in the city, including the hyperlocal and emerging places, as well as outdoor recreational spaces overlooked by city guidebooks and maps [40], [42], [90]. Non-commercial participatory game Urban Shaper developed for high-school pupils, reveals that the youth of Płock (Poland) exhibit interest in public places, which are located not further than $600 \mathrm{~m}$ from their respective schools [68].

\section{Pervasive Games}

The advancement of GPS mobile devices gave birth to location-based games, from low-tech geocaching to high-tech Pokémon Go, which successfully activated the once neglected spaces [17], [40], [90]. Location-based games are also referred to as "pervasive", since they extend beyond the "magic circle" of the game, the spatiotemporal frame, invading public spaces and engaging outsiders [93]. Pervasive participatory games vary from multi-player games, which treat the public space as a playground (e.g. Big Urban Game; ZWERM), to single-player applications for mobile devices, which encourage certain location-based activities (e.g. Play Before Plan; Change Explorer) [11], [50], [61], [72]. The benefits of pervasive games depend on their purpose and design. A four week long game ZWERM is reported to nurture face-to-face communication and community cohesion in two adjacent residential districts of Ghent [72]. The interaction among neighbourhood residents was achieved by means of an interactive device in the shape of a tree, installed in the heart of each neighborhood, which required combo (two people at once) checkins [72]. The device produced a honeypot effect, attracting new participants and generating spin-off activities, such as check-in parties and scheduled check-ins [72]. An Apple watch application for sourcing location-based information ChangeExplorer claims to increase the number of contributions by means of notifications popping-up upon approaching the area under planning [11]. In contrast to most participatory games, which are designed for the laymen, a series of pervasive games Play Before Plan is developed for urban practitioners, such as planners, architects and policy makers [61]. These games enlighten professionals about the local spatial practices at Rye Lane Street in London, which differ substantially from perspective top-down plans and policies, through a series of missions aimed at visiting characteristic locations and communicating with local businessmen [61].

\section{E. Deliberative Games}

The information flow in participatory activities is classified into one-way and two-way flow [45]. One-way information flow, from sponsors to participants and vice versa, is limited to informing participants about planning activities or sourcing contributions from participants, whereas two-way information flow enables deliberation between the sponsors and participants [45]. Civic engagement methods, including a share of participatory games, are often limited to one-way information flow (e.g. a share of information sourcing and sharing games) [14]. Traditional methods enabling information exchange, such as public hearings or thematic discussions, are often characterized by the dominance of vociferous individuals or groups who aim to express their concerns and revolve around a limited set of topics [8], [10]. Furthermore, unless the discussions are recorded and transcribed verbatim, the conclusions are captured for further use, while the discourses are usually left out [10], [45]. The aforementioned deficiencies may be addressed by engaging into discussions well-trained facilitators and observers, which is rarely the case [10], [45], [94]. Therefore, a number of participatory games are designed for facilitating deliberation and capturing the data generated in the process. The card game Community Conversational encourages every participant to speak out and to diversify discourses by means of action and question cards [10]. The discourses are being recorded with a camera aided by the software, which traces the cards, allowing to perform searches within the massive qualitative data [10]. Speaking out or acting in turns fostered dialogue, where all opinions are expressed and heard, enabling building empathy and widening individual perspectives [10]. Role-play games, Play[Location] and Participation Game, foster players to act and reason from alternative positions (roles) while collectively shaping a common vision for a particular area by means of three-dimensional construction units [19], [60]. The role-play fosters consensus building among stakeholders with diverging or even conflicting interests through taking on the opponent's perspective (role) [19], [60], [95].

\section{F. Co-designed Games}

Participatory games often create a framework for a co-design activity (e.g. collective vision for the future development of a neighbourhood), but are rarely co-designed [56], [96]. The game 
mechanics is usually developed by experts with limited involvement from the part of perspective players, who have to follow the established rules, choices and ramifications [97], [98]. The practice is supported by the traditional body of literature in game design promoting the completed unambiguous set of rules as a prerequisite for a game [93], [99]. Participatory games, as a part of serious game domain, use game mechanics to achieve serious outcomes through an entertaining process, thus posing a severe design challenge [21], [78]. The challenge may be addressed by bringing into the design process perspective players who become active co-designers, rather than passive informants [54], [56], [98], [100]. The co-design approach is believed to align games with players' preferences, mitigates the knowledge gaps, and provides the space for mutual learning [98], [100]. The findings from research on game co-design indicate that playing with an existing barebone game prototype yields better results than designing a game from scratch [54], [56], [98]. The barebone prototype encourages the introduction of new rules and narratives while scaffolding the relationships between game elements, emerging experiences and anticipated outcomes [54], [56], [98]. In the course of iterative co-design procedures, applied for creating board games City Makers, Energy Safari and Participation Game, the initial game underwent substantial transformations, and initial game objectives were adjusted accordingly [54], [56], [60]. The playful co-design procedure did not result into substantial reframing of existing planning models and discourses, as was expected earlier [56], [60]. Thus, further research should focus on structuring co-design procedure to trigger triple-loop learning [56], [60].

\section{G. Educational Games}

A share of participatory games focuses on education with no intention to produce planning related outcomes. Education (or learning) and entertainment are the fundamental features of games [21]. Some scholars believe that entertainment stems from learning, as the latter is an enjoyable activity for humans [101]. In-game learning represents a set of progressive challenges with continuous support and instant customized feedback enabling active learning (or learning by doing), which is believed to be more efficient than passive learning (e.g. lecturing) [21]. Games provide space for experimentation, which allows exploring a range of choices and their ramifications without facing real-life undesirable consequences in case of failure and receiving in-game reward in case of success [18], [29]. Participation games may play out real-life situations by setting challenges and modelling possible responses, and thus prepare players for real-life action [29]. The characteristic examples are simulation games Urbax 21 and Water Management Game. The former is a role play game, which explores the relationship between the building regulations and socio-economic changes in the city [69]. The latter models possible scenarios for solving drinking water shortage problems in peri-urban communities [70].

\section{Conclusions}

\section{H. The Application of Games in Planning}

Table II matches the themes elaborated in Section II, Findings and Discussion, with criteria outlined in Section I, Methodology. Games have a wide application context, varying in spatial scope from neighbourhood to region. Depending on their nature games involve small and large number of players. Large samples are characteristic for digital games, while small samples - for board games. Many games do not specify player profile, targeting at generic urban population. Some games are designed for specific player groups, such as children (e.g. Pop-up Pest), youth (e.g. Geo-zombie) or representatives of peri-urban communities facing the shortages of drinking water supply (e.g. Water Management Game). A few games set specific criteria for players, aiming at better representation and meaningful contributions (e.g. Play [Location], Energy Safari). The nature of information flow in games varies from communication to participation. Information sourcing and data generation games are limited to public consultation, whereas deliberative and co-designed games by fostering information exchange achieve public participation. Games are usually in the early planning phases, namely, initiation and design, which are the stages where project frameworks are established and key decisions are taken [46]. The aforementioned statement aligns with the findings from the research on the real-life application of games [15]. However, games may be applied also in later phases for studying and reporting the qualities and use patterns of newly built or refurbished spaces, as well as for evaluation purposes.

\section{Games for Better Participation}

To sum up, the current paper reviews scientific publications on participatory games and reveals common research themes. The ongoing research focuses on the motivational aspects of gamified and non-gamified participation, as well as the contribution of game elements, such as reward-systems, appealing story, emotionally captivating gameplay, etc. into better participation. The evidence from case studies suggests that irrespective of motivation to participate gamification yields the increase in the number of participants and contributions per participant. The findings align with the efforts to enable massive participation through gamified online platforms and applications for mobile devices, which succeeded in recruiting hundreds of participants. Online participatory games are not only "fun", they also provide convenient means to participate, capture and analyse player contributions. The information generated while playing location-based games, if analyzed correctly, may supply additional, non-articulated by players, insights into player preferences.

Another branch of the ongoing research focuses on the learning potential of games and, specifically, on civic learning for enabling collective action and change. The empirical evidence suggests that games with deliberation elements and role-play games in particular, enable participants to widen their perspectives and appreciate opposing or diverging positions. Educational games facilitate understanding of existing planning systems, whereas 
game co-design enables questioning and reframing the underlying concepts. The accumulation of knowledge and skills within the resident community, as well as mutual learning between resident and planning communities, fosters transformation of planning institution in pursuit of better participation.

\section{J. The Limitations and Directions for Further Research}

Due to resource constrains current research builds on a limited literature sample, namely, scientific contributions sourced from a single data base, which results into certain bias. Further studies should diversify the literature sample, expanding the search to other relevant contributions (e.g. professional journals) and databases. To examine the real-life application of participatory games an additional research of planning agencies and their daily practices is recommended.

\section{AcKnowledgements}

The research was partially supported by State Culture Capital Foundation (Valsts Kultūrkapitāla Fonds) under grant No. 2017-3-DIA009.

The author declares no conflict of interests.

\section{REFERENCES}

1. Lerner, J. Playing with power: Participatory planning games in Rosario's villas. Latin American Perspectives, 2013, Vol. 20, Issue 189, pp. 185-201. https://doi.org/10.1177/0094582X12467760

2. Shipley, R., Shipley, S. UTZ. Making it Count: A Review of the Value and Techniques for Public Consultation. Journal of Planning Literature, 2012, Vol. 27, Issue 1, pp. 22-42

https://doi.org/10.1177/0885412211413133

3. Horelli, L. A Methodology of Participatory Planning. In Robert B. Bechtel, Robert \& Arza Churchman, ed., Handbook of Environmental Psychology. S.1.: John Wiley \& Sons, 2002, pp. 607-628. ISBN 0-471-40594-9.

4. Aravena, A. My architectural philosophy? Bring the community into the process. TEDGlobal 2014 [online]. TED Ideas worth spreading [cited 13.01.2020]. https://www.ted.com/talks/alejandro_aravena_my architectural philosophy bring the community into the process/discussion? referrer=playlist- 11 must see ted talks

5. BLOCK BY BLOCK. Oür work. Project selection [online]. Block by Block [cited 13.01.2020]. https://www.blockbyblock.org/our-work

6. Connelly, S. Looking inside public involvement: How is it made so ineffective and can we change this? Community Development Journal. 2006 Vol. 41, Issue 1, pp. 13-24. https://doi.org/10.1093/cdj/bsi046

7. Nienhuis, I., Van Dijk, T., De Roo, G. Let's Collaborate! But Who's Really Collaborating? Individual Interests as a Leitmotiv for Urban Renewa and Regeneration Strategies. Planning Theory \& Practice, 2011, Vol. 12 , Issue 1 , pp. 95-109.

https://doi.org/10.1080/14649357.2011.546671

8. Donders, M., Hartmann, T., Kokx, A. E-Participation in Urban Planning: Getting and Keeping Citizens Involved. International Journal of E-Planning Research, 2014, Vol. 3, Issue 2, pp. 54-69.

https://doi.org/10.4018/ijepr.2014040104

9. Rowe, G., Frewer, L.J. Public participation methods: A framework for evaluation. Science, Technology, \& Human Values, 2000, Vol. 25, Issue 1, pp. 2-29. https://doi.org/10.1177/016224390002500101

10. Johnson, I.G., Macdonald, A., Briggs, J., Manuel, J., Salt, K., Flynn E., Vines, J. Community Conversational. In: Proceedings of the 2017 CHI Conference on Human Factors in Computing Systems - CHI '17. S.1. Association for Computing Machinery, 2017, pp. 2320-2333. ISBN 9781-4503-4655-9. https://doi.org/10.1145/3025453.3025559

11. Wilson, A., Tewdwr-Jones, M., Comber, R. Urban planning, public participation and digital technology: App development as a method of generating citizen involvement in local planning process. Environment and Planning B: Planning and Design, 2019, Vol. 46, Issue 2, pp. 286-302 https://doi.org/10.1177/2399808317712515

12. Schneider, S.H., Busse, S. Participatory Budgeting in Germany-A Review of Empirical Findings. International Journal of Public Administration, 2019, Vol. 43, Issue 3, pp. 259-273.

https://doi.org/10.1080/01900692.2018.1426601
13. Kleinhans, R., Van Ham, M., Evans-Cowley, J. Using Social Media and Mobile Technologies to Foster Engagement and Self-Organization in Participatory Urban Planning and Neighbourhood Governance. Planning Practice \& Research, 2015, Vol. 30, Issue 3, pp. 237-247.

https://doi.org/10.1080/02697459.2015.1051320

14. Klamert, K., Münster, S. Child's play - A literature-based survey on gamified tools and methods for fostering public participation in urban planning In: Electronic Participation, 9th IFIP WG 8.5 International Conference, ePart 2017, St. Petersburg, Russia, September 4-7, 2017, Proceedings, S.l.: Springer International Publishing, 2017, pp. 24-33. ISBN 978-3-31964321-2. https://doi.org/10.1007/978-3-319-64322-9 3

15. Ampatzidou, C., Gugerell, K., Constantinescu, T., Devisch, O., Jauschneg, M., Berger, M. All Work and No Play? Facilitating Serious Games and Gamified Applications in Participatory Urban Planning and Governance. Urban Planning, 2018, Vol. 3, Issue 1, pp. 34-46. http://dx.doi.org/10.17645/up.v3i1.1261

16. Minnery, J., Searle, G. Toying with the City? Using the Computer Game $\mathrm{SimCity}^{\mathrm{TM}} 4$ in Planning Education. Planning Practice and Research, 2013, Vol. 29, Issue 1, pp. 41-55.

https://doi.org/10.1080/02697459.2013.829335

17. Potts, R., Jacka, L., Yee, L.H. Can we 'Catch 'em All'? An exploration of the nexus between augmented reality games, urban planning and urban design. Journal of Urban Design, 2017, Vol. 22, Issue 6, pp. 866-880. https://doi.org/10.1080/13574809.2017.1369873

18. Gordon, E., Baldwin-Philippi, J. Playful civic learning: Enabling reflection and lateral trust in game-based public participation. International Journal of Communication, 2014, Vol. 8, Issue 1, pp. 759-786.

19. Tan, E. Negotiation and Design for the Self-Organizing City. Gaming as a method for Urban Design. S.1.: TU Delft, 2014. A+BE |Architecture and the Built Environment. ISBN 978-94-6186-356-0. https://doi.org/10.7480/abe.2014.11

20. Thiel, S.K., Ertiö, T.P., Baldauf, M. Why so serious? The Role of Gamification on Motivation and Engagement in e-Participation. Interaction Design and Architectures, 2017, Vol. 35, pp. 158-181.

21. Winn, B. M. The Design, Play, and Experience Framework. In: Handbook of Research on Effective Electronic Gaming in Education. Hershey, PA, USA: Information Science Reference (an imprint of IGI Global), 2009, pp. 1010-1024. ISBN 978-1-59904-808-6. https://doi.org/10.4018/978-1-59904-808-6.ch058

22. Duke, R. D. Origin and Evolution of Policy Simulation: A Personal Journey. Simulation \& Gaming, 2011, Vol. 42, Issue 3, pp. 342-358. https://doi.org/10.1177/1046878110367570

23. Feldt, A.G. Experience with Simulation / Gaming: 1960-2010. Simulation \& Gaming, 2014, Vol. 45, Issue 3, pp. 283-305. https://doi.org/10.1177/1046878114543983

24. Sanoff, H. Community participation methods in design and planning. New York, NY, USA: John Wiley \& Sons, 2000. 320 p. ISBN 0-471-35545-3.

25. Sanoff, H. Democratic Design: Participation Case Studies in Urban and Small Town Environments. S.1.: VDM Verlag Dr. Müller, 2010. 168 p. ISBN 978-3-639-28830-8.

26. Devisch, O., Poplin, A., Sofronie, S. The Gamification of Civic Participation: Two Experiments in Improving the Skills of Citizens to Reflect Collectively on Spatial Issues. Journal of Urban Technology, 2016, Vol. 23, Issue 2, pp. 81-102. https://doi.org/10.1080/10630732.2015.1102419

27. Thiel, S.-K., Lehner, U., Sturmer, T., Gospodarek, J. Insights from a $\mathrm{m}$-participation prototype in the wild. In: 2015 IEEE International Conference on Pervasive Computing and Communication Workshops (PerCom Workshops 2015). S.1.: IEEE, 2015, pp. 166-171. ISBN 978-1-4799-8425-1. https://doi.org/10.1109/PERCOMW.2015.7134013

28. Thiel, S.-K., Frohlich, P. Gamification as Motivation to Engage in Location-Based Public Participation. In: Georg GARTNER and Haosheng HUANG, ed., Progress in Location-Based Services 2016. S.1.: Springer International Publishing AG, 2017, Lecture notes in Geoinformation and cartography, pp. 399-421. ISBN 978-3-319-47289-8.

https://doi.org/10.1007/978-3-319-47289-8_20

29. Gordon, E., Haas, J., Michelson, B. Civic creativity: Role-playing games in deliberative process. International Journal of Communication, 2017, Vol. 11, pp. 3789-3807.

30. Devisch, O. Should Planners Start Playing Computer Games? Arguments from SimCity and Second Life. Planning Theory \& Practice, 2008, Vol. 9, Issue 2, pp. 209-226. https://doi.org/10.1080/14649350802042231

31. Devisch, O., Gugerell, K., Diephuis, J., Constantinescu, T., Ampatzidou, C., Jauschneg, M. Mini is beautiful. Playing serious mini-games to facilitate collective learning on complex urban processes. Interaction Design and Architecture(s) Journal, 2017, Vol. 35, pp. 141-157.

32. Poplin, A. Games and serious games in urban planning: study cases. In: Computational Science and Its Applications - ICCSA 2011. S.1.: Springer, Berlin, Heidelberg, 2011, pp. 1-14. Lecture Notes in Computer Science. ISBN 978-3-642-21887-3.

https://doi.org/10.1007/978-3-642-21887-3 1 
33. Poplin, A. Playful public participation in urban planning: A case study for online serious games. Computers Environment and Urban Systems, 2012 Vol. 36, Issue 3, pp. 195-206.

https://doi.org/10.1016/j.compenvurbsys.2011.10.003

34. Poplin, A. Digital serious game for urban planning: „B3-Design your Marketplace!" Environment and Planning B: Planning and Design, 2014, Vol. 41, pp. 493-511. https://doi.org/10.1068/b39032

35. Poplin, A., Shenk, L., Passe, U. Transforming Pervasive into Collaborative: Engaging Youth as Leaders with GIS through a Framework that Integrates Technologies, Storytelling, and Action. Interaction Design and Architecture(s) Journal, 2017, Vol. 35, pp. 182-204.

36. The A-Z of social research: a dictionary of key social science research concepts (Eds.: R. L. Miller, J.D. Brewer). London; Thousand Oaks, Calif: SAGE, 2003. 362 p. ISBN 978-0-7619-7132-0.

37. Taylor, D. The Literature Review: A Few Tips on Conducting It. Univer sity of Toronto. Writing Advice [online, cited 13.01.2020]. https://advice. writing.utoronto.ca/types-of-writing/literature-review/

38. Creswell, J. W. Research Design: Oualitative, Quantitative and Mixed Method Approaches. 3rd edition. Thousand Oaks, California, USA: SAGE Publications, 2009. 296 p. ISBN 978-1-4129-6557-6.

39. Saunders, M. N. K., Lewis, P., Thornhill, A. Research methods for business students. 7th edition. Edinburgh Gate, Harlow, Essex, England: Pearson Education Ltd., 2016. 768 p. ISBN 978-1-292-01662-7.

40. Cord, A. F., Roessiger, F., Schwarz, N. Geocaching data as an indicator for recreational ecosystem services in urban areas: Exploring spatia gradients, preferences and motivations. Landscape and Urban Planning, 2015, Vol. 144, pp. 151-162. https://doi.org/10.1016/j.landurbplan.2015.08.015

41. Eklund, A. Gaming the Real World [online]. Plethora-project [cited 13.01.2020]. https://www.plethora-project.com/gaming-the-real-world

42. Stark, E. Playful places: Uncovering hidden heritage with Ingress. In: So cial, Casual and Mobile Games: The changing gaming landscape. New York: Bloomsbury Academic, 2016. ISBN 978-1-5013-1060-7.

43. Charmaz, K. Constructing grounded theory. London, UK: Sage Publications, 2006. 416 p. ISBN 978-0-7619-7352-2

44. IAP2 International Association for Public Participation. Core Values, Ethics, Spectrum - The 3 Pillars of Public Participation. IAP2 International Association for Public Participation. Resources, 2018 [online]. IAP2 [cited 14.01.2020]. https://www.iap2.org/page/pillars

45. Rowe, G., Frewer, L. J. A typology of public engagement mechanisms. Science Technology and Human Values, 2005, Vol. 30, Issue 2, pp. 251-290. https://doi.org/10.1177/0162243904271724

46. Hamdi, N., Goethert, R. Action planning for cities: a guide to community practice. Chichester; New York: John Wiley, 1997. 264 p. ISBN 978-0 471-96928-0.

47. Wates, N. The community planning handbook: how people can shape their cities, towns and villages in any part of the world. London: Earthscan, 2000. 240 p. ISBN 978-1-85383-654-1.

48. ENGAGEMENT LAB. What's@stake? [online]. atstakegame [cited 14.01.2020]. https://atstakegame.org

49. Hummel, K. @Stake: A Role-Playing Card Game. 18. September 2015 [online]. NCDD. Resource Center [cited 14.01.2020]. http://ncdd.org/rc/ item/10150/

50. Cameron, K. Using a B.U.G. to Promote Urban Design. 1. March 2004 [online]. Metropolis [cited 14.01.2020]. http://www.metropolismag.com/ cities/using-a-b-u-g-to-promote-urban-design/

51. Ferri, G., Coppock, P. Serious Urban Games. From play in the city to play for the city. In: Media and the City: Urbanism, Technology and Communication [Eds.: Simone Tosoni, Matteo Tarantino and Chiara Giaccardi] S.1.: Cambridge Scholars Publishing, 2013, pp. 120-134. ISBN 978-1-44384943-2.

52. Salen, K. Big Urban Game [online]. Katie Salen. Selekted Work [cited 14.01.2020]. https://www.katiesalen.me/projects\#/big-urban-game/

53. STEVENMN01. B.U.G. Blue Day 1, 3. June 2011 [online]. YouTube Video [cited 14.01.2020]. https://www.youtube.com/watch?v=2opyxELpaHM

54. Constantinescu, T. I., Devisch, O., Kostov, G. City Makers: Insights on the Development of a Serious Game to Support Collective Reflection and Knowledge Transfer in Participatory Processes. International Journal of E-Planning Research, 2017, Vol. 6, Issue 4. https://doi.org/10.4018/IJEPR.2017100103

55. INSHENGXIA. What is „Community PlanIt", 9 February 2013 [online] YouTube Video [cited 14.01.2020]. https://www.youtube.com/watch? $=\mathrm{w}$ cJ09qtkOpw

56. Gugerell, K., Zuidema, C. Gaming for the energy transition. Experimenting and learning in co-designing a serious game prototype. Journal of Cleaner Production, 2017, Vol. 169, pp. 105-116. https://doi.org/10.1016/j.jclepro.2017.04.142

57. Prilenska, V. Serious game for modelling neighbourhood energy supply scenarios. In: SBE19 Thessaloniki - Sustainability in the built environment for climate change mitigation. 23-25 October 2019, Conference Proceedings. S.1.: IOP Science.

58. PLAY!UC. Floating City [online]. Play!UC Playing with Urban Complexity [cited 14.01.2020]. http://play-uc.net/?page id=529
59. Prandi, C., Roccetti, M., Salomoni, P. Valentina NISI and Nuno Jardim NUNES. Fighting exclusion: a multimedia mobile app with zombies and maps as a medium for civic engagement and design. Multimedia Tools and Applications, 2017, Vol. 76, pp. 4951-4979.

https://doi.org/10.1007/s11042-016-3780-9

60. Prilenska, V. Participation Game. Reflections on the iterative design process. PlaNext. In print.

61. Valdez Young, A. Play Before Plan: Games for the Public and Planners to Value the Street. Journal of Urban Technology, 2015, Vol. 22, Issue 3 , pp. 97-119. https://doi.org/10.1080/10630732.2015.1040299

62. Valdez Young, A. Shopomama. 25 August 2012 [online]. ISSUU [cited 23.08.2019]. https://issuu.com/betterthanliving/docs/shopomama

63. Valdez Young, A. Arrivalocity. 25 August 2012 [online]. ISSUU [cited 23.08.2019]. https://issuu.com/betterthanliving/docs/arrivalocity

64. Valdez Young, A. Pech City, 25 August 2012 [online]. ISSUU [cited 23.08.2019]. https://issuu.com/betterthanliving/docs/pechcity

65. KULTÚRAKTIV. Games: Pop-up Pest [online]. KULTÚRAKTÍV [cited 23.08.2019]. https://kulturaktiv.hu/en/projects/pop-up-pest/

66. Toth, E., Poplin, A. Pop-up Pest: An Educational Game for Active Participation of Children and Youth in Urban Planning. In: REAL CORP 2013. Planning Times You better keep planning or you get in deep water, for the cities they are a-changin'. Proceedings of 18th International Conference on Urban Planning Regional Development and Information Society. Schwechat-Rannersdorf, Austria: CORP - Competence Center of Urban and Regional Planning, 2013, pp. 731-741. ISBN 978-3-9503110-4-4.

67. Toth, E., Poplin, A. ParticiPécs - a cooperative game fostering learning about the built environment and urban planning. In: 17th AGILE Conference on Geographic Information Science (AGILE 2014), Workshop Geogames and Geoplay, June 03-06, 2014, Castellón, Spain. 2014

68. Olszewski, R., Turek, A., Laczynski, M. Urban Gamification as a Source of Information for Spatial Data Analysis and Predictive Participatory Modelling of a City's Development. In: Proceedings of the 5th International Conference on Data Management Technologies and Applications - Vol. 1: DATA. 2016, pp. 176-181. https://doi.org/10.5220/0006005201760181

69. LOGIVILLE Urbax 21. Simulation pédagogique de l'aménagement urbain [online]. Urbax 21. [cited 23.08.2019]. https://www.urbax.eu/en/presentation-2/

70. Gomes, S. L., Hermans, L. M., Islam, K. F., Huda, S. N., Hossain, Z., Thissen, W.A.H. Capacity Building for Water Management in Peri-Urban Communities, Bangladesh: A Simulation-Gaming Approach. Water, 2018, Vol. 10, pp. 1704-1723. https://doi.org/10.3390/w10111704

71. ILAB.O.ZWERM [online]. Player Vimeo [cited 23.08.2019]. https://player. vimeo.com/video/65648085

72. Laureyssens, T., Coenen, T., Claeys, L., Mechant, P., Criel, J., Van De Moere, A. ZWERM: A modular component network approach for an urban participation game. In: CHI '14: Proceedings of the SIGCHI Conference on Human Factors in Computing Systems, 2014, pp. 3259-3268. https://doi.org/10.1145/2556288.2557053

73. Deterding, S., Dixon, D., Khaled, R., Nacke, L. From game design elements to gamefulness: Defining gamification. In: MindTrek '11: Proceedings of the 15th International Academic MindTrek Conference: Envisioning Future Media Environments, 2011, pp. 9-15. https://doi.org/10.1145/2181037.2181040

74. Leao, S., Izadpahani, P. Factors Motivating Citizen Engagement in Mobile Sensing: Insights from a Survey of Non-Participants. Journal of Urban Technology, 2016, Vol. 23, Issue 4, pp. 85-103. https://doi.org/10.1080/10630732.2016.117582

75. Bowser, A. E., Hansen, D. L., Raphael, J., Reid, M., Gamett, R. J. He, Y. R., Rotman, D., Preece, J. J. Prototyping in PLACE: A Scalable Approach to Developing Location-Based Apps and Games. In: CHI '13: Proceedings of the SIGCHI Conference on Human Factors in Computing Systems, 2013, pp. 1519-1528. https://doi.org/10.1145/2470654.2466202

76. Bowser, A., Hansen, D., Preece, J., He, Y., Boston, C., Hammock, J. Gamifying citizen science: A study of two user groups. In: CSCW Companion '14: Proceedings of the companion publication of the 17th ACM conference on Computer supported cooperative work \& social computing, 2014, pp. 137-140. https://doi.org/10.1145/2556420.2556502

77. Raczkowsky, F. Making Points the Point - Towards a History of Ideas of Gamification. In: Mathias Fuchs, Sonia Fizek, Paolo Ruffino and Niklas Schape, ed., Rethinking Gamification. Lüneburg, Germany: Meson Press, Hybrid Publishing Lab, Leuphana University of Lüneburg, n.d., pp.141- 160. ISBN 978-3-95796-000-9.

78. Bogost, I. Persuasive Games: Exploitationware, 3 May 2011 [online] Gamasutra [cited 14.01.2020]. https://www.gamasutra.com/view/feature/134735/persuasive games exploitationware.php

79. Yannakakis, G. N., Paiva, A. Emmotion in Games. In: The Oxford Hand book of Affective Computing [Eds.: Rafael Calvo, Sidney D'Mello, Jonathan Gratch and Arvid Kappas]. S.1.: Oxford University Press, 2014. ISBN 978-0-19-994223-7. 
80. Geher, G. Video Games and Emotional States. why your kid is addicted to Fortnite, 3 September 2018 [online]. Psychology Today [cited 14.01.2020]. https://www.psychologytoday.com/intl/blog/darwins-subterranean-world/201809/video-games-and-emotional-states

81. Nicholson, S. A User-Centered Theoretical Framework for Meaningful Gamification. In: Games+Learning+Society 8.0. June 13-15, 2012, 2013 , $658 \mathrm{p}$.

82. Brown, G., Kyttä, M. Key issues and research priorities for public participation GIS (PPGIS): A synthesis based on empirical research. Applied Geography, 2014, Vol. 46, pp. 122-136.

https://doi.org/10.1016/j.apgeog.2013.11.004

83. Wiggins, A. Free as in puppies. In: Proc. CSCW 2013, 2013, pp. 1469-1480 https://doi.org/10.1145/2441776.2441942

84. Ertiö, T.-P. Participatory Apps for Urban Planning-Space for Improvement. Planning Practice \& Research, 2015, Vol. 30, Issue 3, pp. 303-321. https://doi.org/10.1080/02697459.2015.1052942

85. Kahila-Tani, M., Broberg, A., Kyttä, M., Tyger, T. Let the Citizens Map-Public Participation GIS as a Planning Support System in the Helsinki Master Plan Process. Planning Practice and Research, 2016, Vol. 31 Issue 2, pp. 195-214. https://doi.org/10.1080/02697459.2015.1104203

86. Eräranta, S., Kahila-Tani, M., Nummi-Sund, P. Web-based Public Participation in Urban Planning Competitions: International Journal of E-Planning Research, 2015, Vol. 4, Issue 1, pp. 1-18.

https://doi.org/10.4018/ijepr.2015010101

87. EESTI ARHITEKTUURIKESKUS. Main Street: giving public spaces back to people [online]. Peatänav [cited 14.01.2020]. http://www.peatanav. ee/en

88. Oser, J., Hooghe, M., Marien, S. Is Online Participation Distinct from Offline Participation? A Latent Class Analysis of Participation Types and Their Stratification. Political Research Quarterly, 2013, Vol. 66, Issue 1, pp. 91-101. https://doi.org/10.1177/1065912912436695

89. Krek, A. Rational Ignorance of the Citizens in Public Participatory Planning Alenka Krek. In: Manfred SCHRENK, ed., CORP 2005 GEO MULTIMEDIAProceedings $10^{\text {th }}$ International Conference on Information \& Communication Technologies (ICT) in Urban Planning and Spatial Development and Impacts of ICT on Physical Space. S.1.: Department of computer aided planning and architecture, Vienna University of Technology, 2005, pp. 165-169. ISBN 3-901673-12-1.

90. Graells-Garrido, E., Ferres, L., Caro, D., Bravo, L. The effect of Pokémon Go on the pulse of the city: a natural experiment. EPJ Data Science, 2017, Vol. 6, Issue 1, p. 23. https://doi.org/10.1140/epjds/s13688-017-0119-3

91. Thakuriah, P., Tilahun, N. Y., Zellner, M. Big Data and Urban Informatics: Innovations and Challenges to Urban Planning and Knowledge Discovery. In: Seeing Cities Through Big Data [Eds.: Piyushimita Thakuriah, Nebiyou Tilahun and Moira Zellner]. Cham: Springer International Publishing, 2017, pp. 11-45.

https://doi.org/10.1007/978-3-319-40902-3 2

92. Goodspeed, R. Digital knowledge technologies in planning practice: from black boxes to media for collaborative inquiry. Planning Theory \& Practice, 2016, Vol. 17, Issue 4, pp. 577-600.

https://doi.org/10.1080/14649357.2016.1212996

93. Rodriguez, $\mathbf{H}$. The playful and the serious: An approximation to Huizinga's Homo Ludens, 2006 [online]. Game Studies [cited 14.01.2020]. http:/ gamestudies.org/0601/articles/rodriges
94. Van Dijk, T., Ubels, H. How Dutch professionals conduct interactive design sessions to foster 'shared understanding'. Environment and Planning B: Planning and Design, 2015, Vol. 43, Issue 3, pp. 464-479. https://doi.org/10.1177/0265813515617658

95. Innes, J. E., Booher, D.E. Consensus Building as Role Playing and Bricolage. Journal of the American Planning Association, 1999, Vol. 65, Issue 1, pp. 9-26. https://doi.org/10.1080/01944369908976031

96. Sotamaa, O., Ermi, L., Laukkanen, T., Mäyrä, F., Nummela, J. The Role of Players in Game Design: A Methodological Perspective. In: Proceedings of Digital Experience: Design, Aesthetics, Practice. DAC 2005. 2005 , pp. 35-42.

97. Isbister, K., Flanagan, M., Hash, C. Designing games for learning: insights from conversations with designers. In: the 28th international conference: Proceedings of the 28th international conference on Human factors in computing systems - CHI '10. Atlanta, Georgia, USA: ACM Press, 2010, p. 204. https://doi.org/10.1145/1753326.1753637

98. Khaled, R., Vasalou, A. Bridging serious games and participatory design. International Journal of Child-Computer Interaction, 2014, Vol. 2 Issue 2, pp. 93-100. https://doi.org/10.1016/j.ijcci.2014.03.001

99. Adams, E. Fundamentals of game design. Third edition. Berkeley, CA: New Riders, 2014. 576 p. ISBN 978-0-321-92967-9.

100. Luck, R. What is it that makes participation in design participatory design? Design Studies, 2018, Vol. 59, pp. 1-8. https://doi.org/10.1016/j.destud.2018.10.002

101. Gee, J. P. Good Video Games and Good Learning: Collected Essays on Video Games, Learning and Literacy. 2nd edition. S.1.: Peter Lang Inc. International Academic Publishers, 2013. 194 p. ISBN 978-1-4331-2393-1.

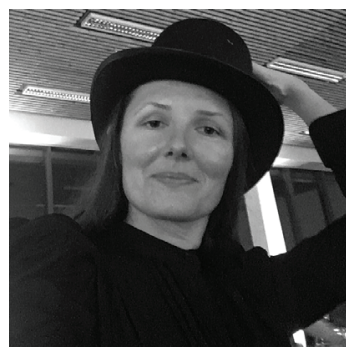

Viktorija Prilenska is currently a PhD student at Tallinn University of Technology, practicing architect and urban planner, co-founder, board member and project manager at NGO Urban Narratives. In 2009, Viktorija received a Diploma in Architecture from Riga Technical University. In 2012, Viktorija graduated from Delft University of Technology with a Master of Science degree in Urbanism. Her professional competences include spatial planning for neighbourhoods (incl. mobility planning, planning and design of recreational spaces), development of building regulations for neighbourhoods, building construction and refurbishment, small-scale water structures. Her current research interests include sustainable mobility and energy planning for cities and neighbourhoods, civic engagement in urban design, planning and policy-making (with focus on gamified participation methods).

\section{Contact Data}

Viktorija Prilenska

E-mail: vprilenska@gmail.com

Phone +371 25340187

Appendix

TABLE I

List of Reviewed Participatory Games [Author of the Article]

\begin{tabular}{|c|c|c|c|c|c|}
\hline No. & Name & Description & Designer & Year & References \\
\hline 1. & @Stake & $\begin{array}{l}\text { Role-play card game for fostering empathy and creativi- } \\
\text { ty }\end{array}$ & Engagement Lab, Emerson College & 2014-2015 & $\begin{array}{l}{[29],[48],} \\
{[49]}\end{array}$ \\
\hline 2. & $\begin{array}{l}\text { B3 - Design Your Mar- } \\
\text { ketplace! }\end{array}$ & $\begin{array}{l}\text { Desktop/laptop application for modelling public spaces } \\
\text { in three dimensions }\end{array}$ & HafenCity University & 2009 & [32], [34] \\
\hline 3. & Big Urban Game & $\begin{array}{l}\text { City wide five day long race in groups carrying } 7.6 \mathrm{~m} \\
\text { tall inflatable figures through a series of checkpoints }\end{array}$ & $\begin{array}{l}\text { Design Institute, University of } \\
\text { Minnesota }\end{array}$ & 2003 & {$[50]-[53]$} \\
\hline 4. & Change Explorer & $\begin{array}{l}\text { Apple Watch application (complemented by iPhone ap- } \\
\text { plication) for conducting geo-referenced surveys }\end{array}$ & $\begin{array}{l}\text { Digital Civics, Newcastle Univer- } \\
\text { sity }\end{array}$ & 2015 & [11] \\
\hline 5. & City Makers & $\begin{array}{l}\text { Card game for education about street businesses and } \\
\text { fostering collaboration }\end{array}$ & $\begin{array}{c}\text { Play!(UC), University of Gron- } \\
\text { ingen }\end{array}$ & n.d. & {$[31],[54]$} \\
\hline 6. & Community Circles ${ }^{1}$ & $\begin{array}{l}\text { Smartphone application for collecting and sharing } \\
\text { geo-referenced content (problems, ideas, photographs) }\end{array}$ & $\begin{array}{l}\text { Telecommunication Research Cen- } \\
\text { ter Vienna }\end{array}$ & n.d. & $\begin{array}{l}{[20],[27],} \\
{[28]}\end{array}$ \\
\hline
\end{tabular}




\begin{tabular}{|c|c|c|c|c|c|}
\hline No. & Name & Description & Designer & Year & References \\
\hline 7. & $\begin{array}{l}\text { Community Conversa- } \\
\text { tional }\end{array}$ & $\begin{array}{l}\text { Board game for dialogue building with video and } \\
\text { geo-referenced content capturing, and audio content } \\
\text { transcription into text }\end{array}$ & Open Lab, Newcastle University & n.d. & {$[10]$} \\
\hline 8. & Community PlanIt & $\begin{array}{l}\text { Desktop/laptop application for collecting and sharing } \\
\text { geo-referenced content (problems, ideas, photographs) }\end{array}$ & Engagement Lab, Emerson College & $2011-2012$ & {$[18],[55]$} \\
\hline 9. & Energy Safary ${ }^{2}$ & $\begin{array}{l}\text { Board game for education about energy transition and } \\
\text { fostering collaboration }\end{array}$ & $\begin{array}{c}\text { Play!(UC), University of Gron- } \\
\text { ingen }\end{array}$ & 2016 & {$[31],[56]$} \\
\hline 10. & Energy Game & $\begin{array}{c}\text { A prototype of a digital game (developed in Unity, } \\
\text { available through GitHub) for building neighbourhood } \\
\text { energy supply scenarios }\end{array}$ & $\begin{array}{l}\text { Viktorija Prilenska, Tallinn Uni- } \\
\text { versity of Technology; Māris } \\
\text { Lenšs, Emīls Terjavjainens, Nor- } \\
\text { munds Budevičs, Girts Upītis and } \\
\text { Liene Versune, Albert College }\end{array}$ & 2018-2019 & {$[57]$} \\
\hline 11. & Floating City & $\begin{array}{l}\text { Idea collecting application for a computing device (e.g. } \\
\text { desktop, smartphone) }\end{array}$ & $\begin{array}{c}\text { Play!(UC), University of Gron- } \\
\text { ingen }\end{array}$ & n.d. & [31], [58] \\
\hline 12. & Geo-Zombie & $\begin{array}{l}\text { Smartphone application for crowdsourcing geo-refer- } \\
\text { enced accessibility data (text, photographs) for physical } \\
\text { spaces }\end{array}$ & $\begin{array}{l}\text { Catia Prandi, Marco Roccetti and } \\
\text { Paola Salomoni, Department of } \\
\text { Computer Science and Engineer- } \\
\text { ing, University of Bologna; Valen- } \\
\text { tina Nisi and Nuno Jardim Nunes, } \\
\text { Madeira Interactive Technologies } \\
\text { Institute, University of Madeira }\end{array}$ & n.d. & {$[59]$} \\
\hline 13. & HINT! & $\begin{array}{l}\text { Smartphone application for crowdsourcing geo-refer- } \\
\text { enced accessibility data (text, photographs) for physical } \\
\text { spaces }\end{array}$ & $\begin{array}{l}\text { Catia Prandi, Marco Roccetti and } \\
\text { Paola Salomoni, Department of } \\
\text { Computer Science and Engineer- } \\
\text { ing, University of Bologna; Valen- } \\
\text { tina Nisi and Nuno Jardim Nunes, } \\
\text { Madeira Interactive Technologies } \\
\text { Institute, University of Madeira }\end{array}$ & n.d. & {$[59]$} \\
\hline 14. & NextCampus & $\begin{array}{c}\text { A prototype (physical model + Excel calculation sheets) } \\
\text { of a digital game for scenario building about university } \\
\text { campus relocation }\end{array}$ & $\begin{array}{l}\text { Alenka Poplin, D. Kulus, T. Prill, } \\
\text { A. Wagner, HafenCity University }\end{array}$ & 2009 & {$[33]$} \\
\hline 15. & Participation game & $\begin{array}{l}\text { Role-play board game for negotiating alternatives and } \\
\text { collectively constructing neighbourhood project }\end{array}$ & $\begin{array}{l}\text { Viktorija Prilenska, Tallinn Uni- } \\
\text { versity of Technology }\end{array}$ & 2018-2019 & {$[60]$} \\
\hline 16. & Play Before Plan ${ }^{3}$ & $\begin{array}{l}\text { Smartphone application for planners and other urban } \\
\text { practitioners to learn from spatial and economic strate- } \\
\text { gies applied in Rye lane }\end{array}$ & $\begin{array}{l}\text { Adriana Valdez Young, littleBits } \\
\text { and English for Action }\end{array}$ & 2012 & {$[61]-[64]$} \\
\hline 17. & Play $\left[\right.$ Location] ${ }^{4}$ & $\begin{array}{l}\text { Role-play board game for co-designing a neighbour- } \\
\text { hood vision }\end{array}$ & Play the City & $2011-2015$ & [19] \\
\hline 18. & Pop-up Pest & $\begin{array}{c}\text { Game in public space, which educates children about } \\
\text { spatial aspects of downtown Pest }\end{array}$ & $\begin{array}{l}\text { Eszter Toth, HafenCity University } \\
\text { in co-operation with kulturAktiv }\end{array}$ & 2012 & {$[65]-[67]$} \\
\hline 19. & Urban Shaper & $\begin{array}{l}\text { Group problem solving game for high-school pupils, } \\
\text { which focuses on urban regeneration issues and collects } \\
\text { geo-referenced data }\end{array}$ & $\begin{array}{c}\text { Robert Olszewski, Agnieszka } \\
\text { Turek, and Marcin Łączyński, } \\
\text { Warsaw University of Technology } \\
\text { and University of Warsaw }\end{array}$ & 2016 & {$[68]$} \\
\hline 20. & Urbax 21 & $\begin{array}{l}\text { Role-play game with hybrid interface (digital + pen and } \\
\text { paper) for educating student and agency representatives } \\
\text { about urban policy issues }\end{array}$ & Thierry Vilmin & n.d. & [69] \\
\hline 21. & $\begin{array}{l}\text { Water management } \\
\text { game (originally, no } \\
\text { name) }\end{array}$ & $\begin{array}{l}\text { Role-play board game for educating rural-urban fringe } \\
\text { residents about drinking water management }\end{array}$ & $\begin{array}{c}\text { Sharlene L. Gomes, Leon M. } \\
\text { Hermans and Wil A.H. Thissen, } \\
\text { Faculty of Technology, Policy, and } \\
\text { Management, Delft University of } \\
\text { Technology }\end{array}$ & 2018 & {$[70]$} \\
\hline
\end{tabular}




\begin{tabular}{|c|c|c|c|c|}
\hline No. & Name & Description & Designer & References \\
\hline 22. & ZWERM & $\begin{array}{c}\text { Neighbourhood wide four week long pervasive com- } \\
\text { munity-building game, supported by a network of hard- } \\
\text { ware elements across the neighbourhood }\end{array}$ & imec iLab.o & 2013 \\
\hline
\end{tabular}

n.d. - no date.

${ }^{1}$ Two versions of the application were developed: a gamified and non-gamified; the game was tested in real-life under the name "Täsä" in Turku, Finland

2 "Energy Safari" has a modification - "Mobility Safari", which uses similar interface and game mechanics, and focuses on smart mobility.

${ }^{3}$ The series of applications "Play Before Plan" includes two games, "Arrivalocity" and "Shopomama", as well as a non-gamified app "Pech City". Print version is also available.

${ }^{4}$ The series of games "Play[Location]" includes an array of iteratively developed games from the early prototypes "Play Almere Haven" and "Play Oude Western", through an intermediate prototype "Play Istanbul", to full-fledged games: "Play Noord" and "Play Oosterwold".

TABLE II

Summary of Themes and Criteria with Examples [Author of the Article]

\begin{tabular}{|c|c|c|c|c|c|}
\hline Themes & $\begin{array}{l}\text { Context: neigh- } \\
\text { bourhood, city, } \\
\text { region }\end{array}$ & $\begin{array}{l}\text { Number (large, } \\
\text { small) and pro- } \\
\text { file (defined, un- } \\
\text { defined) of par- } \\
\text { ticipants (large, } \\
\text { small) }\end{array}$ & $\begin{array}{l}\text { Participation level: } \\
\text { communication, } \\
\text { consultation, par- } \\
\text { ticipation }\end{array}$ & $\begin{array}{l}\text { Planning phase: } \\
\text { initiation, de- } \\
\text { sign, implemen- } \\
\text { tation, mainte- } \\
\text { nance }\end{array}$ & Examples \\
\hline $\begin{array}{l}\text { Information sourcing } \\
\text { games }\end{array}$ & $\begin{array}{l}\text { neighbourhood } \\
\text { or city }\end{array}$ & large, undefined & consultation & design & $\begin{array}{l}\text { Change Explorer, Community Circles, Commu- } \\
\text { nity Planit, Floating City, Geo-zombie, HINT! }\end{array}$ \\
\hline Data generation games & $\begin{array}{l}\text { neighbourhood } \\
\text { or city }\end{array}$ & large, undefined & consultation & design & $\begin{array}{c}\text { B3 - Design Your Marketplace, Urban Shaper, } \\
\text { Energy Game, NetCampus }\end{array}$ \\
\hline Pervasive games & $\begin{array}{l}\text { neighbourhood } \\
\text { or city }\end{array}$ & small, undefined & $\begin{array}{l}\text { communication or } \\
\text { consultation }\end{array}$ & $\begin{array}{l}\text { either } \mathrm{n} / \mathrm{a} \text {, or } \\
\text { design }\end{array}$ & $\begin{array}{c}\text { Big Urban Game, Change Eplorer, Community } \\
\text { Circles, Geo-zombie, HINT! Play Before Plan, } \\
\text { ZWERM }\end{array}$ \\
\hline Deliberative games & neighbourhood & $\begin{array}{l}\text { small, defined or } \\
\text { undefined }\end{array}$ & $\begin{array}{l}\text { communication, } \\
\text { consultation or par- } \\
\text { ticipation }\end{array}$ & design & $\begin{array}{l}\text { @Stake, Community Conversational, } \\
\text { Play[Location], Participation Game }\end{array}$ \\
\hline Co-designed games & $\begin{array}{l}\text { neighbourhood } \\
\text { or city }\end{array}$ & small, defined & $\begin{array}{l}\text { communication, } \\
\text { consultation or par- } \\
\text { ticipation }\end{array}$ & $\begin{array}{l}\text { either } \mathrm{n} / \mathrm{a} \text {, or ini- } \\
\text { tiation }\end{array}$ & City Makers, Energy Safari, Participation Game \\
\hline Educational Games & $\begin{array}{l}\text { neighbourhood, } \\
\text { city or region }\end{array}$ & $\begin{array}{l}\text { small, defined or } \\
\text { undefined }\end{array}$ & communication & $\begin{array}{l}\text { either } \mathrm{n} / \mathrm{a} \text {, or ini- } \\
\text { tiation }\end{array}$ & $\begin{array}{c}\text { Pop-up Pest, Urbax21, Water Management } \\
\text { Game }\end{array}$ \\
\hline
\end{tabular}

